University of Nebraska - Lincoln

DigitalCommons@University of Nebraska - Lincoln

1980

\title{
TESTOSTERONE INFLUENCES ON GROWTH, PERFORMANCE, CARCASS CHARACTERISTICS AND COMPOSITION OF YOUNG MARKET LAMBS
}

B. D. Schanbacher

USDA-ARS

J. D. Crouse

USDA-ARS

C. L. Ferrell

USDA-ARS

Follow this and additional works at: https://digitalcommons.unl.edu/usdaarsfacpub

Part of the Agricultural Science Commons

Schanbacher, B. D.; Crouse, J. D.; and Ferrell, C. L., "TESTOSTERONE INFLUENCES ON GROWTH, PERFORMANCE, CARCASS CHARACTERISTICS AND COMPOSITION OF YOUNG MARKET LAMBS" (1980). Publications from USDA-ARS / UNL Faculty. 760.

https://digitalcommons.unl.edu/usdaarsfacpub/760

This Article is brought to you for free and open access by the U.S. Department of Agriculture: Agricultural Research Service, Lincoln, Nebraska at DigitalCommons@University of Nebraska - Lincoln. It has been accepted for inclusion in Publications from USDA-ARS / UNL Faculty by an authorized administrator of DigitalCommons@University of Nebraska - Lincoln. 


\title{
TESTOSTERONE INFLUENCES ON GROWTH, PERFORMANCE, CARCASS CHARACTERISTICS AND COMPOSITION OF YOUNG MARKET LAMBS'
}

\author{
B. D. Schanbacher, J. D. Crouse and C. L. Ferrell \\ US Department of Agriculture ${ }^{2,3}$ \\ Clay Center, Nebraska 68933
}

\begin{abstract}
Summary
Ram lambs, wethers and wethers implanted with Silastic capsules containing crystalline testerone were placed on test at $14.9 \pm 1.1 \mathrm{~kg}$ and evaluated for differences in growth, performance, carcass characteristics and composition. Silastic implants that were able to maintain physiological concentrations of serum testosterone provided appropriate replacement therapy in wethers. Growth rate, efficiency of feed utilization and carcass yield of intact ram lambs and testosterone-implanted wethers were superior to the corresponding traits of wethers. Wethers had greater backfat thickness and percentage kidney and pelvic fat, and their carcasses graded higher than those of ram lambs or wethers implanted with a high dosage of testosterone. Empty body composition was significantly affected by treatment. Thus, intact rams contained more water and protein but less fat and gross energy than wethers. Testosteroneimplanted wethers were intermediate in composition. Carcass water and protein were not significantly affected by treatment; however, carcass fat and gross energy were highest for wethers and lowest for intact rams. The relationship between testosterone and carcass fat and energy was dose dependent; i.e., decreased fat and energy were associated with
\end{abstract}

\footnotetext{
${ }^{1}$ The authors acknowledge the technical assistance of Ms. Becky Weber, Mr. Lee Peshek, Mr. Brad Knapp and Mr. Wayne Hinerman and the cooperation of the Nebraska Agr. Exp. Sta., Univ. of Nebraska, Lincoln. Parts of these data were presented at the 1979 Annu. Meet. of the ASAS (Schanbacher et al., 1979), Univ. of Arizona, Tucson, July 28-31.

${ }^{2}$ Roman L. Hruska US Meat Anim. Res. Center, AR, SEA.

${ }^{3}$ Mention of a trade name, proprietary product or specific equipment does not constitute a guarantee or warranty of the product by the USDA and does not imply its approval to the exclusion of other products that may also be suitable.
}

increased serum testosterone. In conclusion, testosterone appears to be the principal testicular hormone responsible for the superior performance and preferred carcass traits characteristic of young market rams.

(Key Words: Ram Lambs, Testosterone, Growth, Carcass, Composition.)

\section{Introduction}

Ram lambs grow more rapidly, utilize feed more efficiently and yield leaner carcasses than do wethers (Walker, 1950; McClaugherty et al., 1959; Wilson et al., 1970, 1972; Glimp, 1971). These beneficial responses are assumed to be attributable to testicular hormones, particularly testosterone. Schanbacher and Ford (1976) found growth and carcass responses of intact and short scrotum rams to be superior to those of castrate lambs. In spite of marked differences between intact and short scrotum rams in testicular weight and histology and serum luteinizing hormone concentrations, serum testosterone was remarkably similar. Thus, the superior growth responses of these animals were attributed to the high blood concentrations of testosterone.

Exogenous testosterone has been shown to improve rate of gain and feed efficiency of lambs (Andrews et al., 1949; Pope et al., 1950; O'Mary et al., 1952; Jacobs et al., 1972); however, testosterone may not be the only testicular hormone that improves performance of the growing-finishing animal. Hafs et al. (1971) emphasized that anabolic effects in ruminants could be derived from both androgens and estrogens. Jacobs et al. (1972) found intact rams and testosterone-treated wethers similar in carcass traits; however, rams gained faster than treated wethers. These data suggest that testicular hormones in addition to testosterone are needed to maximize growth performance of young lambs. To study the effectiveness of 685 
testicular endocrine secretions on performance of growing finishing wethers one must have a suitable treatment regimen that provides physiological concentrations of blood testosterone. Testosterone-filled Silastic capsules deliver a predictable dose of testosterone to lambs (Schanbacher, 1980b), making it possible to study the relationship between testosterone treatment and lamb performance.

\section{Materials and Methods}

Sixty crossbred ram lambs born in October 1977 were used in this study. The lambs were randomly divided into six groups of 10 and assigned to treatment at 10 weeks of age (15 $\mathrm{kg}$ ). Except for 10 lambs that were slaughtered initially and analyzed for estimation of chemical composition at the start of the experiment, the lambs $(n=50)$ were treated as indicated in the preceding companion study (Schanbacher, $1980 \mathrm{~b})$. In brief, 10 lambs were left intact ( $R$ ) and the remainder were castrated. Ten wethers were implanted with an empty Silastic capsule (W); 10 were implanted with two $10-\mathrm{cm}$ Silastic capsules to provide a low blood concentration of testosterone $\left(\mathrm{W}_{\mathrm{L}}\right) ; 10$ were implanted with two $30-\mathrm{cm}$ Silastic capsules to provide an intermediate blood concentration of testosterone $\left(\mathrm{W}_{\mathrm{I}}\right)$ and 10 were implanted with six 30 $\mathrm{cm}$ Silastic capsules to provide a high blood concentration of testosterone $\left(W_{H}\right)$, Subsequently, lambs in groups $\mathrm{R}, \mathrm{W}, \mathrm{W}_{\mathrm{L}}, \mathrm{W}_{\mathrm{I}}$ and $\mathrm{W}_{\mathrm{H}}$ were penned individually and fed ad libitum a pelleted diet consisting of $71 \%$ ground shell corn, $20 \%$ dehydrated alfalfa $5 \%$ soybean meal and $1.3 \%$ trace mineralized salt. The diet contained $88.5 \%$ dry matter, $13.6 \%$ crude protein and $2.90 \mathrm{Mcal}$ metabolizable energy $/ \mathrm{kg}$ dry matter. Feed consumption was tabulated daily, animals were weighted biweekly and weights were recorded until all animals had been slaughtered.

Lambs in each treatment group were stratified by weight at approximately $30 \mathrm{~kg}$ and assigned to slaughter group 1 (36 kg) or slaughter group $2(52 \mathrm{~kg})$. At slaughter, testosterone implants were retrieved and hot carcass weight was recorded. The gastrointestinal tract was cleared and total weight of noncarcass tissues (offal) was recorded. Chilled carcass data were collected $24 \mathrm{hr}$ later and used to calculate quality and yield grades. The offal and carcass of each lamb were frozen $(-20 \mathrm{C})$ and later ground in a
Hobart (Model 4732) grinder equipped with a 5-mm screen. After thorough mixing, triplicate $100 \mathrm{~g}$ samples of both the offal and carcass were taken and the weight of each was recorded. Dry weight was recorded after freeze drying to constant weight, and fat-free dry weight was recorded after extraction with diethyl ether in Soxhlet apparatuses for 7 days. Fat was calculated as the difference between dry weight before and after ether extraction. Samples were then ground in a Wiley mill equipped with a $1-\mathrm{mm}$ screen. Total nitrogen was determined by an automated Kjeldahl procedure, ash by burning in a muffle furnace at $575 \mathrm{C}$ for $8 \mathrm{hr}$ and gross energy by adiabatic bomb calorimetry.

Empty body composition was calculated as the sum of the carcass and offal components, and empty body gains were calculated as the difference between empty body or component weight at slaughter and empty body or component weight of lambs in the initial slaughter group.

The data were analyzed by analysis of variance for data with unequal subclass numbers (Harvey, 1975); the model included treatment and slaughter group as main effects. Initial weight and deviations from slaughter group mean empty body weight were included as linear covariates. Interactions between main effects were evaluated and found to be statistically nonsignificant. Therefore, the data for 36- and $52-\mathrm{kg}$ slaughter lambs were pooled for presentation. Where $F$ values were significant, group means were tested by Fisher's LSD test $(\mathrm{P}<.05)$.

\section{Results}

Influences of Castration and Testosterone Treatment on Serum Testosterone Concentrations. Serum testosterone was low $(.2 \mathrm{ng} / \mathrm{ml})$ in castrate lambs but ranged from .6 to 3.1 $\mathrm{ng} / \mathrm{ml}$ during pubertal development in intact rams. Testosterone-filled Silastic implants resulted in an immediate increase in serum testosterone concentrations in castrate lambs, but concentrations decreased thereafter as the lambs grew. Serum testosterone decreased from 1.2 to $.5 \mathrm{ng} / \mathrm{ml}$ in wethers implanted with the low $\left(\mathrm{W}_{\mathrm{L}}\right)$ testosterone dosage; from 2.8 to $.9 \mathrm{ng} / \mathrm{ml}$ in wethers implanted with the intermediate $\left(\mathrm{W}_{\mathrm{I}}\right)$ testosterone dosage, and from 6.6 to $1.9 \mathrm{ng} / \mathrm{ml}$ in wethers implanted with the high $\left(\mathrm{W}_{\mathrm{H}}\right)$ testosterone dosage (Schanbacher, 1980b). Because serum testosterone concentra- 
tions were not static, data are expressed in terms of low, intermediate and high dosages instead of actual blood concentrations.

Testosterone Influences on Growtb Rate and Feed Utilization. Growth rate was reduced $(\mathrm{P}<.05)$ by castration, but this effect was partly offset by exogenous testosterone (table 1). Although rate of gain increased in a dosedependent manner for wethers implanted with low and intermediate levels of testosterone, two slow-growing wethers implanted with a high level of testosterone caused that group $\left(W_{H}\right)$ to perform poorly. Efficiency of feed utilization showed a trend similar to that of average daily gain. Intact rams were most efficient, requiring only $3.8 \mathrm{~kg}$ feed $/ \mathrm{kg}$ gain; wethers were least efficient, requiring $4.3 \mathrm{~kg}$ feed $/ \mathrm{kg}$ gain, and testosterone-implanted wethers required an intermediate amount of feed. Intake of metabolizable energy, like intake of dry feed, was higher for wethers than for rams and was decreased by testosterone (table 1). Metabolizable energy requirement per unit gain was similarly affected.

Testosterone Influences on Carcass Characteristics. Adjusted backfat thickness was lowest $(.48 \mathrm{~cm})$ for intact rams and highest $(.69$ $\mathrm{cm}$ ) for wethers (table 2). External fat was negatively associated with the dosage of testosterone implanted, and backfat thickness was only $.46 \mathrm{~cm}$ in wethers implanted with a high level of testosterone, a value comparable to that measured for intact rams. Although the percentage of kidney and pelvic fat was lowest for intact rams and highest for wethers, a dose-dependent suppression of this internal depot by testosterone was not evident. Carcass quality was negatively related to testosterone treatment; wethers graded significantly higher than rams and testosterone-implanted wethers. Intact rams and wethers implanted with a high level of testosterone graded similarly. Carcass yields were high for all lambs but treatment differences were still found $(P<.05)$. In contrast to quality grades, yield grades were highest for intact rams and wethers implanted with a high level of testosterone. The high yield grades and somewhat low quality grades determined for lambs in this study were due largely to the inclusion of an early slaughter group (36-kg lambs).

The influence of slaughter weight on carcass quality and yield is illustrated in figures 1 and 2 , respectively. Changes in quality grade between 36 and $52 \mathrm{~kg}$ were nearly parallel for all treatment groups. Wethers went from low Choice at $36 \mathrm{~kg}$ to high Choice at $52 \mathrm{~kg}$, whereas intact rams went from high Good to low Choice. Testosterone-implanted wethers were intermediate at both weights. On the other hand, percentage cutability was similar (45.7) for all lambs at $36 \mathrm{~kg}$ but differed $(\mathrm{P}<.05)$ at $52 \mathrm{~kg}$ $\left(\mathrm{R}, 44.3 \mathrm{~W}, 41.8 ; \mathrm{W}_{\mathrm{L}}, 42.7 ; \mathrm{W}_{\mathrm{I}}, 43.3 ; \mathrm{W}_{\mathrm{H}}\right.$, 44.0). This difference suggests that the influences of testosterone on carcass yield are determined primarily during the late finishing stage for lambs rather than during the early growing stage.

Testosterone Influences on Empty Body and Carcass Composition. Weight and composition of intact rams, wethers and testosteronetreated wethers and their carcasses are shown in tables 3 and 4 . Although body weights did not

TABLE 1. AVERAGE DAILY GAIN, DRY FEED INTAKE AND UTILIZATION OF METABOLIZABLE ENERGY (ME) BY INTACT RAMS (R), WETHERS (W) AND TESTOSTERONE-IMPLANTED (LOW $\left[W_{L}\right]$, INTERMEDIATE $\left[W_{I}\right]$ AND HIGH $\left[W_{H}\right]$ ) WETHERS

\begin{tabular}{|c|c|c|c|c|c|}
\hline Group & $\begin{array}{l}\text { Avg daily } \\
\text { gain, } \\
\text { g/day }\end{array}$ & $\begin{array}{l}\text { Total dry } \\
\text { feed intake, } \\
\mathrm{kg}\end{array}$ & $\begin{array}{l}\text { Total ME } \\
\text { intake, } \\
\text { Mcal }\end{array}$ & $\begin{array}{l}\text { Dry feed } \\
\text { per gain, } \\
\mathrm{kg} / \mathrm{kg}\end{array}$ & $\begin{array}{l}\text { ME } \\
\text { per gain, } \\
\text { Mcal } / \mathrm{kg}\end{array}$ \\
\hline $\begin{array}{l}R \\
W \\
W_{L} \\
W_{I} \\
W_{H} \\
S E \\
\text { Level of } \\
\text { significance }\end{array}$ & $\begin{array}{c}342^{\mathrm{a}} \\
205^{\mathrm{b}} \\
280^{\mathrm{bc}} \\
318^{\mathrm{ac}} \\
259 \mathrm{bc} \\
31 \\
\mathrm{P}<.05\end{array}$ & $\begin{array}{l}109^{\mathrm{a}} \\
121^{\mathrm{b}} \\
121^{\mathrm{b}} \\
112^{\mathrm{a}} \\
115^{\mathrm{ab}} \\
\quad 3 \\
\\
P<.05\end{array}$ & $\begin{array}{c}316^{\mathrm{a}} \\
348^{\mathrm{b}} \\
350^{\mathrm{b}} \\
322^{\mathrm{a}} \\
332^{\mathrm{ab}} \\
\quad 9 \\
\mathrm{P}<.05\end{array}$ & $\begin{array}{l}3.8^{\mathrm{a}} \\
4.3^{\mathrm{b}} \\
4.3^{\mathrm{b}} \\
3.9^{\mathrm{a}} \\
4.1^{\mathrm{ab}} \\
.14 \\
P<.10\end{array}$ & $\begin{array}{c}11.1^{\mathrm{a}} \\
12.5^{\mathrm{b}} \\
12.3^{\mathrm{b}} \\
11.2^{\mathrm{a}} \\
11.7^{\mathrm{ab}} \\
.4 \\
\mathrm{p}<.10\end{array}$ \\
\hline
\end{tabular}

$a, b, c$ Means not followed by the same superscript are different $(P<.05)$.' 
TABLE 2. CARCASS CHARACTERISTICS OF INTACT RAMS (R), WETHERS (W) AND TESTOSTERONE-IMPLANTED (LOW $\left[W_{L}\right]$, INTERMEDIATE $\left[W_{l}\right.$ ] AND HIGH $\left[W_{H}\right]$ ) WETHERS ${ }^{a}$

\begin{tabular}{|c|c|c|c|c|}
\hline Group & $\begin{array}{l}\text { Adjusted } \\
\text { backfat } \\
\text { thickness, } \\
\mathrm{cm}\end{array}$ & $\begin{array}{l}\text { Kidney and } \\
\text { pelvic } \\
\text { fat, } \\
\%\end{array}$ & $\begin{array}{l}\text { Quality } \\
\text { gradeb }^{\mathrm{b}}\end{array}$ & $\begin{array}{l}\text { Yield } \\
\text { gradec }^{c}\end{array}$ \\
\hline $\begin{array}{l}R \\
W^{\prime} \\
W_{L} \\
W_{I} \\
W_{H} \\
S E \\
\text { Level of } \\
\text { significance }\end{array}$ & $\begin{array}{l}.48^{\mathrm{d}} \\
.69^{\mathrm{e}} \\
.63^{\mathrm{ef}} \\
.51^{\mathrm{df}} \\
.46^{\mathrm{d}} \\
.05 \\
P<.05\end{array}$ & $\begin{array}{c}2.91^{\mathrm{d}} \\
4.01^{\mathrm{e}} \\
3.12^{\mathrm{d}} \\
4.13^{\mathrm{e}} \\
4.13^{\mathrm{e}} \\
.29 \\
\mathrm{p}<.01\end{array}$ & $\begin{array}{c}9.98^{\mathrm{d}} \\
11.21^{\mathrm{e}} \\
10.47^{\mathrm{d}} \\
10.22^{\mathrm{d}} \\
9.97^{\mathrm{d}} \\
.25 \\
P<.01\end{array}$ & $\begin{array}{l}1.60^{\mathrm{d}} \\
1.84^{\mathrm{ef}} \\
1.81^{\mathrm{ef}} \\
1.68^{\mathrm{df}} \\
1.60^{\mathrm{d}} \\
.07 \\
P<.05\end{array}$ \\
\hline
\end{tabular}

${ }^{\mathrm{a}}$ Data for 36- and $52-\mathrm{kg}$ slaughter lambs are pooled.

${ }^{b}$ Quality grade: $10=$ low Choice, $11=$ average Choice, $12=$ high Choice.

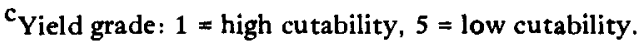

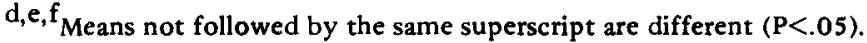

differ, carcass weights were affected by treatment; wether carcasses were heavier $(P<.05)$ than ram carcasses. Although carcass composition was affected by treatment only for fat and energy content, empty body composition was different for content of water, fat, protein and

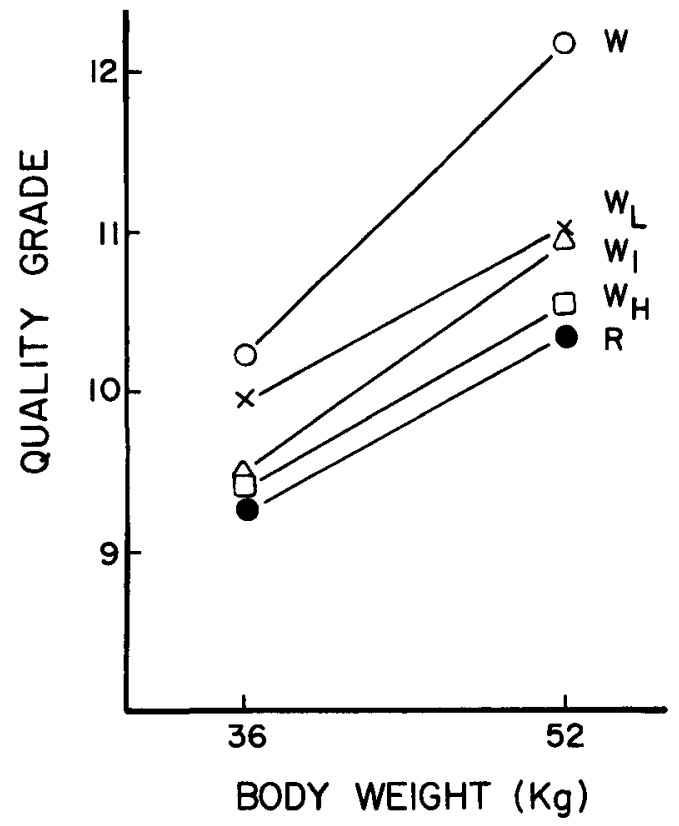

Figure 1. Quality grades $(10=$ low Choice, $11=$ average Choice, 12 = high (hoice) as a function of body weight for intact rams (R), wethers (W) and testosterone-implanted wethers $\left(W_{L}, W_{I}, W_{H}\right)$. energy. In general, intact rams and wethers implanted with high levels of testosterone were leaner and contained less fat and energy than nonimplanted wethers.

Weight and composition of empty body gains of intact rams, wethers and testosterone-

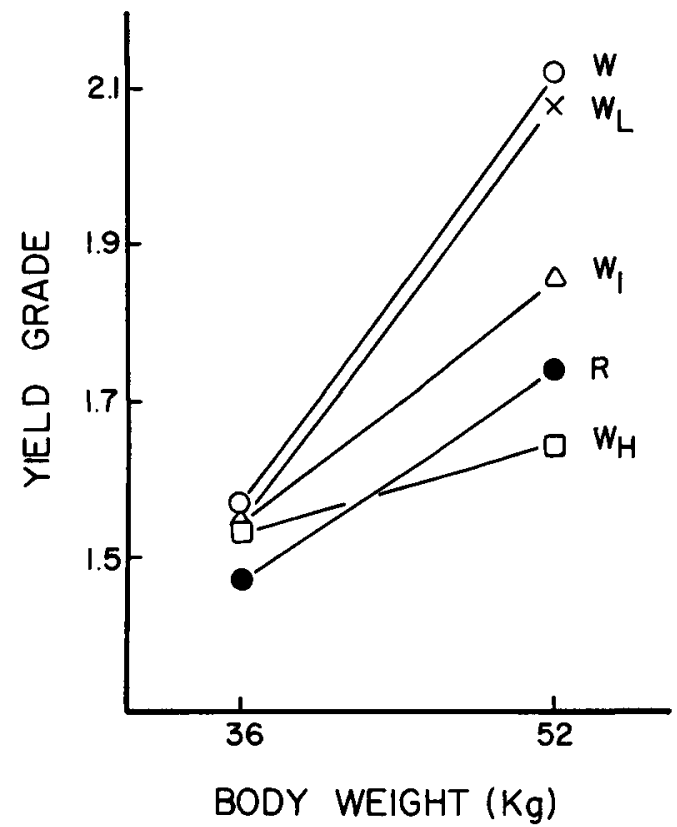

Figure 2. Yield grades $(1=$ high cutability, $5=$ low cutability as a function of body weight for intact rams $(R)$, wethers $(W)$ and testosterone-implanted wethers $\left(W_{L}, W_{I}, W_{H}\right)$. 
TABLE 3. EMPTY BODY WEIGHT AND COMPOSITION OF INTACT RAMS (R), WETHERS (W) AND TESTOSTERONE-IMPLANTED (LOW $\left[\mathrm{w}_{\mathbf{L}}\right.$ ], INTERMEDIATED $\left[\mathrm{W}_{1}\right]$ AND HIGH $\left[\mathrm{W}_{\mathrm{H}_{\mathrm{H}}}\right]$ ) WETHERS ${ }^{\mathrm{a}}$

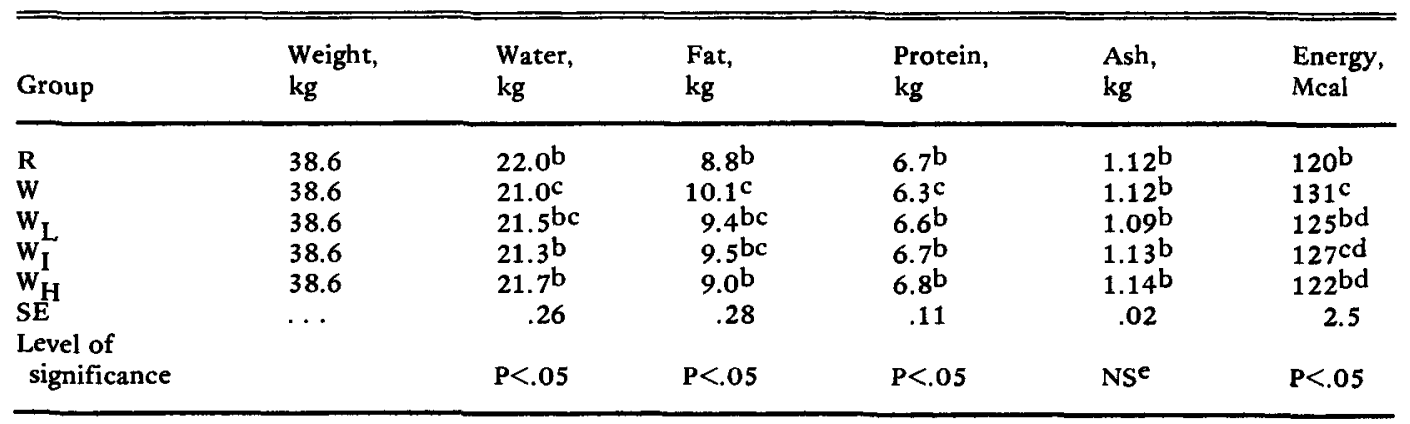

${ }^{\mathrm{a}}$ Data for 36- and 52-kg slaughter lambs are pooled.

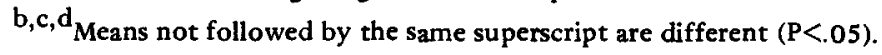

$e_{\text {Not significant. }}$

implanted wethers are shown in table 5. Composition of gains reflected carcass and empty body compositon. Intact rams and testosterone-implanted wethers had more protein and less fat and energy than nonimplanted wethers.

\section{Discussion}

The results of this study support previous findings that ram lambs gain more rapidly, utilize feed more efficiently and yield leaner carcasses than do wethers (Field, 1971; Schanbacher and Ford, 1976). Testosterone is presumed to be the testicular hormone responsible for these effects (Schanbacher and Ford, 1976) even though the testis is though to secrete substantial quantities of other steroids.
In an effort to determine whether blood concentrations of testosterone in ram lambs are responsible for their superior performance, testes were removed and exogenous testosterone was administered in physiological dosages to the growing-finishing lamb. Testosterone-filled Silastic capsules were used successfully to produce mean serum testosterone concentrations similar to those observed for intact ram lambs (Schanbacher, 1980b). The similar performance of intact lambs and wethers implanted with the high dosage of testosterone indicates that this single steroid possesses most if not all the anabolic effects that the testes provide. Results of previous investigations with wethers injected (Jacobs et al., 1972) or subcutaneously implanted (Andrews et al., 1949;

TABLE 4. CARCASS WEIGHT AND COMPOSITION OF INTACT RAMS (R), WETHERS (W) AND TESTOSTERONE-IMPLANTED (LOW [ $W_{L}$ ], INTERMEDIATE $\left[W_{I}\right.$ ] AND HIGH [ $\left.W_{H}\right]$ ) WETHERS ${ }^{a}$

\begin{tabular}{|c|c|c|c|c|c|c|}
\hline Group & $\begin{array}{l}\text { Weight, } \\
\text { kg }\end{array}$ & $\begin{array}{l}\text { Water, } \\
\text { kg }\end{array}$ & $\begin{array}{l}\text { Fat, } \\
\text { kg }\end{array}$ & $\begin{array}{l}\text { Protein, } \\
\text { kg }\end{array}$ & $\begin{array}{l}\text { Ash, } \\
\text { kg }\end{array}$ & $\begin{array}{l}\text { Energy, } \\
\text { Mcal }\end{array}$ \\
\hline $\begin{array}{l}R \\
W^{\prime} \\
W_{L} \\
w_{I} \\
W_{H} \\
S E \\
\text { Level of } \\
\text { significance }\end{array}$ & $\begin{array}{c}22.2^{\mathrm{bd}} \\
22.8^{\mathrm{b}} \\
22.6^{\mathrm{b}} \\
22.4^{\mathrm{bd}} \\
21.7^{\mathrm{cd}} \\
.28 \\
P<.05\end{array}$ & $\begin{array}{r}12.4^{b} \\
12.2^{b} \\
12.4^{b} \\
12.3^{b} \\
12.3^{b} \\
.25 \\
N^{e}\end{array}$ & $\begin{array}{l}5.6^{\mathrm{d}} \\
6.5^{\mathrm{c}} \\
6.1^{\mathrm{bc}} \\
5.9^{\mathrm{b}} \\
5.3^{\mathrm{b}} \\
.21 \\
\\
P<.01\end{array}$ & $\begin{array}{l}3.4^{\mathrm{b}} \\
3.3^{\mathrm{b}} \\
3.3^{\mathrm{b}} \\
3.5^{\mathrm{b}} \\
3.4^{\mathrm{b}} \\
.06 \\
\mathrm{NS}^{\mathrm{e}}\end{array}$ & $\begin{array}{l}.77^{b} \\
.76^{b} \\
.72^{b} \\
.76^{b} \\
.75^{b} \\
.02 \\
N s^{e}\end{array}$ & $\begin{array}{l}72^{b} \\
80^{c d} \\
76^{b d} \\
75^{b d} \\
69^{b} \\
2 \\
\\
P<.01\end{array}$ \\
\hline
\end{tabular}

${ }^{a}$ Data for 36- and $52-\mathrm{kg}$ slaughter lambs are pooled.

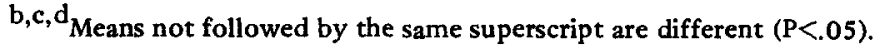

ent significant. 
TABLE 5. WEIGHT AND COMPOSITION OF EMPTY BODY GAINS OF INTACT RAMS (R), WETHERS (W) AND TESTOSTERONE-IMPLANTED (LOW [ $\mathrm{W}_{\mathrm{L}}$ ], INTERMEDIATE $\left[\mathrm{W}_{\mathbf{I}}\right.$ ] AND HIGH $\left[\mathrm{W}_{\mathrm{H}}\right.$ ]) WETHERS ${ }^{a}$

\begin{tabular}{|c|c|c|c|c|c|c|}
\hline Group & $\begin{array}{l}\text { Weight, } \\
\mathrm{kg}\end{array}$ & $\begin{array}{l}\text { Water, } \\
\text { kg }\end{array}$ & $\begin{array}{l}\text { Fat, } \\
\mathrm{kg}\end{array}$ & $\begin{array}{l}\text { Protein, } \\
\mathrm{kg}\end{array}$ & $\begin{array}{l}\text { Ash, } \\
\mathrm{kg}\end{array}$ & $\begin{array}{l}\text { Energy, } \\
\text { Mcal }\end{array}$ \\
\hline $\mathbf{R}$ & 28.5 & $14.8^{b}$ & $8.3^{b}$ & $4.8^{b}$ & $.72^{b}$ & $104^{b}$ \\
\hline $\mathrm{W}$ & 28.5 & $13.8^{\mathrm{c}}$ & $9.6^{c}$ & $4.4^{c}$ & $.72^{\mathrm{b}}$ & $115^{\mathrm{c}}$ \\
\hline $\mathbf{W}_{\mathrm{I}}$ & 28.5 & $14.3^{b c}$ & $8.9 \mathrm{bc}$ & $4.7 \mathrm{~b}$ & $.69 \mathrm{~b}$ & $109 b d$ \\
\hline$w_{I}$ & 28.5 & $14.1^{b}$ & $9.0^{b c}$ & $4.7 \mathrm{~b}$ & $.72^{b}$ & $111^{\mathrm{cd}}$ \\
\hline $\mathrm{w}_{\mathrm{H}}$ & 28.5 & $14.5^{b}$ & $8.5^{b}$ & $4.8^{\mathrm{b}}$ & $.74^{b}$ & $106^{b d}$ \\
\hline$S E$ & $\ldots$ & .26 & .28 & .11 & .02 & 2.5 \\
\hline $\begin{array}{l}\text { Level of } \\
\text { significance }\end{array}$ & $\ldots$ & $\mathrm{P}<.05$ & $\mathrm{P}<.05$ & $\mathrm{P}<.05$ & $\mathrm{NS}^{\mathrm{e}}$ & $\mathrm{P}<.05$ \\
\hline
\end{tabular}

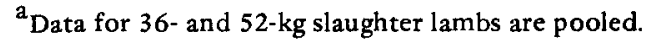

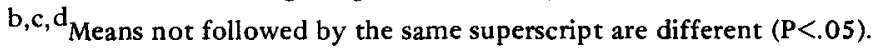

e Not significant.

Pope et al., 1950; O'Mary et al., 1952) with testosterone support the hypothesis that this hormone promotes anabolism in market lambs and produces leaner carcasses more efficiently. Interpretating of these earlier reports are more difficult, however, because of the low and discontinuous administration of testosterone. In the only study in which plasma concentrations of testosterone were measured (Jacobs et al., 1972), testosterone was temporarily increased and became nondetectable during the experiment. Because cessation of hormone therapy or castration may quickly alter the characteristics and composition of the lamb carcass, continuous exposure to testosterone either by testicular secretion or by implants similar to those used in the present study may be necessary to assess the influence of gonadal steroids on lamb performance.

Decreased fat and energy content of carcasses from ram lambs and testosterone-treated wethers resulted in lean carcasses. Jacobs et al. (1972) showed that wethers treated with testosterone enanthate and untreated rams were remarkably similar in all carcass traits, including fat thickness, fat color and fat firmness, whereas untreated wethers were markedly different. In spite of an apparent influence of testosterone on these qualitative aspects of internal and external fat depots, Crouse et al. (1972) found no detectable effects of exogenous testosterone on fatty acid deposition in wethers.

From the results of this study and results reported previously, testosterone appears to be the principal steroid responsible for the su- perior performance of intact ram lambs. Although peripheral metabolism of testosterone may be necessary for anabolic activity, we do not know whether gonadal steroids act directly on the target tissues of protein (muscle) and lipid (adipose) synthesis and degradation or whether they act indirectly through secondary mechanisms. The presence of androgen receptors in skeletal muscle (Dube et al., 1976; Krieg, 1976; Rogozkin, 1979) suggests the possibility of a direct mechanism of action; however, stimulation of the secretion of anabolic hormones such as growth hormone (Davis et al., 1978; Wiggins et al., 1976) and prolactin (Heitzman, 1979; Schanbacher, 1980a) by androgen and estrogen treatment provides an alternative mode of action for gonadal steroids.

\section{Literature Cited}

Andrews, F. N., W. M. Beeson and C. Harper, 1949. The effect of stilbestrol and testosterone on the growth and fattening of lambs. J. Anim. Sci. 8:578.

Crouse, J. D., J. D. Kemp, J. D. Fox, D. G. Ely and W. G. Moody. 1972. Effect of castration, testosterone and slaughter weight on fatty acid content of ovine adipose tissue. J. Anim. Sci. 34:384.

Davis, S. L., D. L. Ohlson, J. Klindt and M. S. Anfinson. 1978. Episodic growth hormone secretory patterns in sheep: Relationship to gonadal steroid hormones. Amer. J. Physiol. 233:E519.

Dube, J. Y., R. Lesage and R. R. Tremblay. 1976. Androgen and estrogen binding in rat skeletal and perineal muscles. Can. J. Biochem. 54:50.

Field, R. A. 1971. Effect of castration on meat quality and quantity. J. Anim. Sci. 32:849.

Glimp, H. A., 1971. Effects of sex alteration, breed, type of rearing and creep feeding on lamb growth. J. Anim. Sci. 32:859.

Hafs, H. D., R. W. Purchas and A. M. Pearson. 1971. A 
review: Relationships of some hormones to growth and carcass quality of ruminants. J. Anim. Sci. 33:64.

Harvey, W. R. 1975. Least-squares analysis of data with unequal subclass numbers. USDA, ARS. H-4.

Heitzman, R. J. 1979. The efficacy and mechanism of action of anabolic agents as growth promoters in farm animals. J. Steroid Biochem. 11:927.

Jacobs, J. A., R. A. Field, M. P. Bolkin, C. C. Kaltenbach and M. L. Riley. 1972. Effects of testoterone enanthate on lamb carcass composition and quality. J. Anim. Sci. 34:30.

Krieg, M. 1976. Characterization of the androgen receptor in the skeletal muscle in the rat. Steroids $28: 261$.

McClaugherty, F. S., R. C. Cartor and J. A. Gaines. 1959. Effects of docking and castration on growth and quality of spring lambs. J. Anim. Sci. $18: 1159$.

O'Mary, C. C., A. L. Pope, G. G. Wilson, R. W. Bray and L. E. Casida. 1952. Effects of diethylstilbestrol, testosterone and progesterone on growth and fattening and certain carcass characteristics of western lambs. J. Anim. Sci. 11:656.

Pope, A. L., C. C. O'Mary, W. E. Batterman, R. W. Bray and L. E. Casida. 1950. The effect of certain steroid hormones on the growth, fattening and carcass quality of heavy lambs, J. Anim. Sci. $9: 680$.

Rogozkin, V. A. 1979. Anabolic steroid metabolism in skeletal muscle. J. Steroid Biochem. 11:923.

Schanbacher, B. D. 1980a. Influence of testicular steroids on thyrotropin releasing hormone-induced prolactin release in mature rams. J. Androl. 1:121.

Schanbacher, B. D. $1980 \mathrm{~b}$. Testosterone regulation of luteinizing hormone and follicle stimulating hormone secretion in young male lambs. J. Anim. Sci. $51: 679$.

Schanbacher, B. D., C. L. Ferrell and J. D. Crouse. 1979. Growth and carcass characteristics of testosterone implanted lambs. J. Anim. Sci. 49 (Suppl. 1):333.

Schanbacher, B. D. and J. J. Ford. 1976. Luteinizing hormone, testosterone, growth and carcass responses to sexual alteration in the ram. J. Anim. Sci. 43:638.

Walker, D. E. 1950. The influence of sex upon carcass quality of New Zealand fat lambs. New Zealand J. Sci. Technol. 32:1.

Wiggins, J. P., L. L. Wilson, H. Rothenbacher and S. L. Davis. 1976. Effects of diethylstilbestrol, zeranol and sex on live, blood metabolite, carcass and endocrine characteristics of lambs. J. Anim. Sci. $43: 518$.

Wilson, L. L., H. Varela-Alvarez, M. C. Rugh and M. L. Borges. 1972. Growth and carcass characteristics of rams, cryptorchids, wethers and ewes subcutaneously implanted with zeranol. J. Anim. Sci. $34: 336$.

Wilson, L. L., J. H. Ziegler, M. C. Rugh, J. L. Watkins, T. L. Merritt, M. J. Simpson and F. L. Kreuzberger. 1970. Comparison of live, slaughter and carcass characteristics of rams, induced cryptorchids and wethers. J. Anim. Sci. 31:455. 